\title{
ANALISIS PELAKSANAAN PELAYANAN PERSALINAN SELAMA PANDEMI COVID-19 BERDASARKAN PENGETAHUAN DAN SIKAP IBU BERSALIN
}

\author{
Mudyawati Kamaruddin ${ }^{1 *}$, Andi Reski Sulpianti ${ }^{2}$, Haerani ${ }^{3}$, Erniawati ${ }^{4}$, Jusni $^{5}$, Artita ${ }^{6}$, Asviratul Annatasia ${ }^{7}$ \\ Nurhidayat Triananins ${ }^{8}$ \\ 1Program Studi Pascasarjana, IImu Laboratorium Medik, Universitas Muhammadiyah Semarang \\ 2,3,4,5,6,7Program Studi Kebidanan, Akademi Kebidanan Tahirah Al Baeti Bulukumba, Sulawesi Selatan \\ *Korespondensi e-mail: mudya07@gmail.com; mudyawati@unimus.ac.id
}

\section{ABSTRACTS COVID-19 PANDEMIC: PREGNANT MOTHERS' KNOWLEDGE AND ATTITUDE REGARDING DELIVERY SERVICES}

Background: Since the Coronavirus disease 2019 (COVID-19) attacked and became an epidemic in practically the whole globe till today, the government has imposed several limitations on almost all regular services, including maternity and newborn health care. This limitation is strictly enforced at the hospital, Community Health Center, and clinic levels. As a result, maternity and newborn health care are among those impacted, in terms of both access and provision.

Purpose: The aim of this study was to explain how delivery services were implemented during the CoViD19 pandemic.

Methods: This research examines maternity care at Hospital of Prof. Dr. H.M. Anwar Makkatutu Bantaeng during the CoViD-19 pandemic. The study began with interviews with four midwives to gain an overview of delivery service implementation, followed by data collecting from women who gave birth at the RSUD with the following inclusive criteria: mothers who gave birth at the RSUD between March 2020 and April 2021 and have got delivery services. Meanwhile, moms who gave birth outside of the required timeline while receiving delivery services at the RSUD were excluded from the study. Test sheets, questionnaires, and tape recorders were utilized as research instruments. The analysis was carried out using a systems approach theory.

Results: Some factors are apparent in the analysis of the execution of delivery services during the CoViD19 pandemic. The characteristics of respondents in reproductive age account for $75 \%$ of input parameters, while multipara accounts for $25 \%$. Midwives provided delivery services to expectant mothers in order to help them cope with the postpartum period. While the output includes analysis results of maternity mothers' knowledge: $55 \%$ have sufficient information, $40 \%$ have high knowledge, and 5\% have little understanding. During the CoViD-19 pandemic, the attitude of maternity mothers toward delivery services was 27 percent positive, and 80 percent were still regarded sufficient.

Conclusion Good knowledge is supported by a positive attitude towards service changes shown by maternity mothers, and that the community already understands the situation of the CoViD-19 pandemic, understands the consequences and effects of not complying with regulations related to the CoViD-19 pandemic.

Suggestion It is hoped that further research can be in the form of a follow-up to the analysis of health services in hospitals both in the city and at the regional level which refers to health protocols in the post-CoViD-19 pandemic.

Keyword: CoViD-19 Pandemic, Pregnant Mothers, Knowledge, Attitude, Delivery Services

\section{ABSTRAK}

Latar Belakang: Sejak Coronavirus disease 2019 (CoViD-19) menyerang dan menjadi wabah di hampir seluruh dunia hingga saat ini, banyak pembatasan yang dilakukan oleh pemerintah hampir ke semua layanan rutin termasuk pelayanan kesehatan ibu dan bayi baru lahir. Pembatasan ini diberlakukan baik di pelayanan kesehatan tingkat Rumah sakit, Pusat Kesehatan Masyarakat maupun tingkat klinik. Akibatnya, pelayanan kesehatan ibu dan bayi baru lahir menjadi salah satu layanan yang terkena dampak, baik dari segi akses maupun pelayanan.

Tujuan: Tujuan penelitian ini untuk mengetahui gambaran pelaksanaan pelayanan persalinan selama masa pandemi CoViD-19.

Metode: Penelitian ini merupakan analisis terhadap pelayanan ibu bersalin selama pandemi CoViD-19 di RSUD Prof. Dr. H.M. Anwar Makkatutu Bantaeng. Penelitian diawali dengan wawancara dengan empat bidan 


\section{JKM (Jurnal Kebidanan Malahayati),Vol 7,No.4.Oktober 2021, ISSN (Print) 2476-8944 ISSN (Online) 2579-762X, Hal 626-633}

untuk mendapatkan gambaran pelaksanaan pelayanan persalinan, dilanjutkan dengan pendataan ibu-ibu yang melahirkan di RSUD tersebut dengan kriteria inklusif sebagai berikut ibu bersalin di bulan Maret 2020 sampai dengan April 2021 dan mendapatkan pelayanan persalinan di RSUD. Sedangkan, ibu bersalin yang diluar rentang waktu ditentukan walaupun mendapatkan pelayanan persalinan di RSUD itu tidak dimasukan dalam sampel. Alat penelitian yang digunakan berupa lembar tes, kuesioner dan tape recorder. Analisis dilakukan dengan teori pendekatan sistem.

Hasil: Analisis pelaksanaan pelayanan persalinan selama masa pandemi CoViD-19 dilihat dari faktor input yaitu karakteristik responden dalam usia subur $75 \%$ responden dan $25 \%$ multipara. Proses: dilakukan pelayanan persalinan oleh bidan untuk membimbing ibu hamil dalam menghadapi persalinan dan masa nifas. Sedangkan output: hasil analisis pengetahuan dan sikap ibu bersalin. Terdapat $55 \%$ berpengetahuan cukup, $40 \%$ berpengetahuan baik, dan $5 \%$ berpengetahuan kurang. Adapun sikap ibu bersalin yang ditunjukan terhadap pelayanan persalinan selama pandemi CoViD-19 yang bersikap baik terhadap pelayanan persalinan rumah sakit adalah $27 \%$, dan yang tergolong cukup berpengetahuan adalah $80 \%$.

Kesimpulan Pengetahuan yang baik didukung dengan sikap yang positif terhadap perubahan-perubahan pelayanan ditunjukan oleh ibu bersalin, dan bahwa masyarakat sudah paham atas situasi pandemi CoViD-19, paham akan akibat dan efek yang ditimbulkan jika tidak menaati regulasi terkait pandemic CoViD-19.

Saran Diharapkan penelitian selanjutnya dapat berupa penindaklanjutan analisis pelayanan kesehatan di Rumah Sakit baik di kota maupun di tingkat daerah yang beracuan pada protokol kesehatan pada masa setelah pandemi CoViD-19.

Keyword: Covid-19 Pandemic, Pregnant Mothers, Knowledge, Attitude, Delivery Services

\section{PENDAHULUAN}

Pandemi CoViD-19 yang pada pada tanggal 11 Maret 2020 ditetapkan sebagai pandemi oleh Badan Kesehatan Dunia (WHO) dengan angka mortalitas sebesar $2,1 \%$ di seluruh dunia, dan terus bertambah hingga tanggal 9 Agustus 2021 kasus terkofirmasi di dunia adalah 203 juta orang. Berdasarkan data dari GugusTugas Percepatan Penanganan (GTPP) CoViD-19 per tanggal 9 Agustus 2021 di Indonesia, jumlah pasien terkonfirmasi sudah mencapai 3. 686.740 orang, pasien sembuh 3.129 .662 atau $84,9 \%$ dari pasien terkonfirmasi, pasien yang meninggal sejumlah 108.571 atau 2,9\%. (Kemenkes, 2021).

Dari seluruh kasus positif CoViD-19 di Indonesia, sebanyak $12,83 \%$ adalah dari kelompok anak, sedangkan anak yang berusia 0-2 tahun sejumlah 44.083 orang yang terkonfirmasi di antaranya meninggal dunia. Dari kelompok ibu hamil, terdapat 536 kasus CoViD-19 pada ibu hamil (Kemenkes, 2021). Data ini menunjukkan bahwa ibu hamil, bersalin, nifas dan bayi barul lahir juga merupakan sasaran yang rentan terhadap infeksi CoViD-19 dan kondisi ini dikhawatirkan akan meningkatkan morbiditas dan mortalitas ibu dan bayi baru lahir. Sebagaimana diketahui masa nifas merupakan kondisi transisi dari melahirkan, penyembuhan luka lahir dan pemulihan kesehatan ibu bersalin (Erniawati \& Kamaruddin, 2020). Selain pada kondisi ini kebutuhan gizi ibu akan meningkat dengan proses percepatan penyembuhan dan pengembalian sistem imun tubuh sediakala
(Kamaruddin, Hasrawati, dkk., 2019). Hal ini diantisipasi oleh Kementerian Kesehatan dalam hal ini Direktorat Kesehatan Keluarga membuat pedoman bagi ibu hamil, bersalin, nifas dan bayi baru lahir. Pedoman ini merupakan acuan bagi ibu dan keluarga serta tenaga kesehatan dalam memberikan pelayanan ANC, persalinan dan PNC selama social distancing di masa pandemi CoViD19, di era adaptasi kebiasaan baru yang diberlakukan mulai bulan Juli 2020 (Kemenkes, 2020).

Ibu hamil dan bersalin diyakini mempunyai risiko lebih tinggi terinfeksi CoViD-19 dan jika terinfeksi akan berisiko terjadi penyakit yang berat, morbiditas dan mortalitas dibandingkan dengan populasi lain. Sampai saat ini, pengetahuan tentang infeksi CoViD-19 dalam hubungannya dengan kehamilan dan janin masih terbatas dan belum ada rekomendasi spesifik untuk penanganan ibu hamil dengan CoViD-19. Walau efek samping pada janin berupa persalinan preterm juga dilaporkan pada ibu hamil dengan infeksi CoViD-19 (Zhu, 2020). Untuk itu, pelayanan Rumah Sakit, Puskesmas maupun klinik persalinan dapat menjadi gerbang dalam pencegahan terjadinya penularan dan meminimalisasi jumlah korban dari akibat virus CoViD-19 ini.

Rumah sakit merupakan salah satu tempat pemberian pelayanan kesehatan kepada masyrakat terutama yang sakit. Strategi dan pencegahan serta kontrol infeksi yang diterapkan oleh bidan dan karyawan penunjang medis adalah dengan lebih 


\section{Mudyawati Kamaruddin, Andi Reski Sulpianti, Haerani, Erniawati, Jusni, Artita, Asviratul Annatasia, Nurhidayat Triananinsi}

menekankan Alat Pelindung Diri (APD) yang dipakai saat bekerja yang sesuai dengan indikasi alat pelindung diri apa yang sebaiknya mereka gunakan saat bekerja. Fungsi APD sebagai alat perlindungan diri dari agen infeksius, baik melalui kontak dengan darah, semua jenis cairan tubuh secret, dan selaput lendir. Selain melindungi, APD juga mengurangi penyebaran infeksi dari pasien (Hayati dan Paija, 2014).

Studi pendahuluan yang dilakukan dengan cara wawancara dengan bidan yang bertugas di bagian pelayanan persalinan RSUD Prof. Dr. H. M. Anwar Makkatutu Bantaeng bahwa masih ada pengunjung Rumah Sakit yang belum sepenuhnya menerapkan protokol kesehatan perilaku masyarakat khususnya ibu hamil dan kader sehingga potensi terjadinya penyebaran virus Covid-19 kemungkinan meningkat.

Terkait dengan pedoman yang didalamnya meliputi protokol kesehatan, selama pandemi CoViD-19 oleh Kementerian Kesehatan RI (Kemenkes, 2020) dan studi pendahuluan yang telah dilakukan yang dijelaskan sebelumnya, sehingga penelitian tentang pengetahuan dan sikap ibu bersalin tentang pelayanan kesehatan dimasa pandemi Covid-19 di rumah sakit Prof. Dr. H. M. Anwar Makkatutu Bantaeng terlaksana.

\section{METODE PENELITIAN}

Penelitian ini menggunakan metode penelitian kuantitatif (analitik) dengan teknik pengambilan sampel secara purposive sampling yaitu teknik penetapan sampel sesuai dengan desain peneliti untuk mengetahui gambaran pelaksanaan pelayanan persalinan pada masa pandemi CoViD-19 di Rumah Sakit rujukan RSUD Prof. Dr. H. M. Anwar Makkatutu Bantaeng, Sulawesi Selatan. Selama pandemi terdapat perubahan pola dalam pelaksanaan pelayanan persalinan dikarenakan adanya aturan pelaksanaan protokol kesehatan untuk menghambat perkembangan dan penyebaran CoViD-19. Analisis terhadap pelayanan ibu bersalin selama pandemi CoViD-19 di RSUD Prof. Dr. H.M. Anwar Makkatutu Bantaeng ini diawali dengan wawancara dengan empat bidan untuk mendapatkan gambaran pelaksanaan pelayanan persalinan, dilanjutkan dengan pendataan ibu-ibu yang melahirkan di RSUD tersebut dengan rentang waktu bersalin antara bulan Maret 2020 sampai dengan April 2021 dan mendapatkan pelayanan persalinan di RSUD.

Populasi pada penelitian ini adalah semua ibu bersalin dan 4 bidan di RSUD Prof. Dr. H. M. Anwar Makkatutu Bantaeng, Sulawesi Selatan. Populasi yang digunakan pada penelitian ini adalah ibu bersalin yang mendapat pelayanan persalinan selama pandemi CoViD-19 dengan jumlah 49. Ibu bersalin yang dijadikan sampel adalah yang memenuhi kriteria inklusif yaitu bersedia untuk diinterview dan mengisi lembar tes terkait pengetahuan dan sikap ibu bersalin terhadap pelayanan RSUD selama pandemi, waktu bersalin masuk dalam kriteria rentang waktu yang ditentukan dan mendapatkan pelayanan selama bersalin di RSUD. Sedangkan, ibu yang bersalin diluar rentang waktu ditentukan walaupun mendapatkan pelayanan persalinan di RSUD itu tidak dimasukan dalam sampel. Sampel yang memenuhi syarat penelitian ini adalah sejumlah 20 orang ibu bersalin. Alat penelitian yang digunakan berupa lembar tes, kuesioner dan media sosial (WhatsApp) sebagai alat komunikasi jarak jauh dengan sampel.

\section{HASIL DAN PEMBAHASAN}

Karakteristik responden ibu bersalin di RSUD Prof. Dr. H. M. Anwar Makkatutu Bantaeng, Sulawesi Selatan yang ditunjukkan pada table 1.

Table 1.

Karakteristik Responden Ibu Bersalin

\begin{tabular}{lcc}
\hline \multirow{1}{*}{ Kategori } & \multicolumn{2}{c}{ Responden } \\
\cline { 2 - 3 } & F = 20 & \% \\
\hline Usia & & \\
Reproduksi sehat & 15 & 75 \\
Reproduksi tidak sehat & 5 & 25 \\
Pendidikan & & \\
Pendidikan dasar & 0 & 0 \\
Pendidikan menengah & 7 & 35 \\
PT & 13 & 65 \\
Pekerjaan & & \\
Bekerja & 5 & 25 \\
Tidak bekerja & 15 & 75 \\
Paritas & & \\
Primipara & 5 & 25 \\
Multipara & 15 & 75
\end{tabular}

Tabel 1 memperlihatkan bahwa karakteristik responden ibu bersalin berdasarkan usia sebagian besar ibu berada pada status usia reproduksi sehat (20-30.tahun) sebanyak 75\%. Berdasarkan pendidikan terakhir yang diselesaikan oleh responden, mayoritas ibu bersalin mempunyai tingkat pendidikan tinggi aitu sebanyak $65 \%$, sedikit lebih tinggi dari responden yang berpendidikan menengah (35\%) dan tidak ada satupun responden yang mempunyai pendidikan rendah. Sebagian besar responden berprofesi sebagai ibu rumah tangga/tidak bekerja $75 \%$. Berdasarkan paritasnya responden dalam status multipara (75\%), Ibu 
melahirkan I-2 kali adalah 25\%, serta tidak ada ibu yang nullipara.

Kegiatan pelayanan persalinan mematuhi pedoman yang ditetapkan di atas dan pelaksanaan protokol kesehatan yang dilakukan petugas menunjukkan adanya dukungan dari petugas kesehatan terhadap pelayanan persalinan selama pandemi CoViD-19. Hasil dari kuesioner yang di isi ibu hamil tentang dukungan petugas diperlihatkan pada gambar 1 :

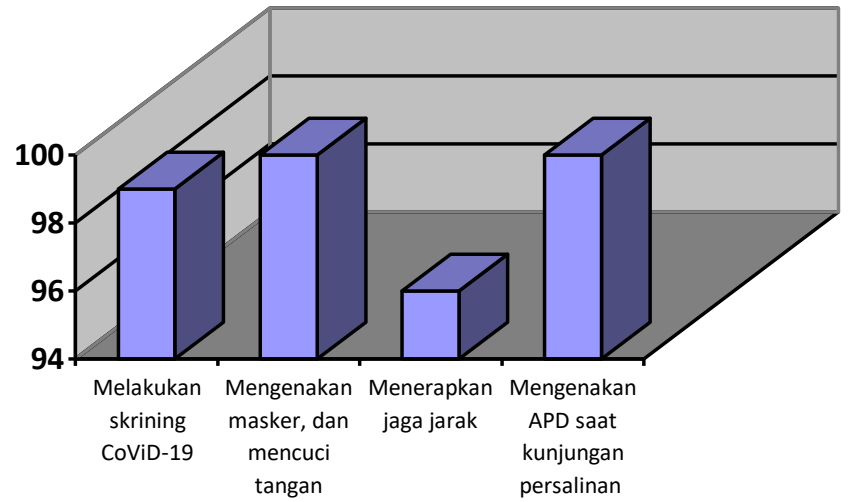

Gambar 1.

Pelayanan persalinan mematuhi pedoman dan protokol kesehatan selama masa pandemi CoViD-19

Peran petugas kesehatan dalam memberikan pelayanan persalinan selama masa pandemi CoViD-19, tidak terlepas dari penerapan protocol kesehatan yang telah ditetapkan dan menjadi regulasi di Rumah Sakit, Puskesmas dan klinik bersalin. Pada Gambar 1 di atas, penerapan jaga jarak memiliki prosentase yang lebih rendah dari regulasi yang lain. Hal ini disebabkan petugas kesehatan bagian pelayanan persalinan tidak dapat menghindari kontak fisik ke pasien dalam memberikan panduan, seperti pemberian ASI pertama saat bayi lahir, kontak fisik saat proses persalinan dan inisiasi menyusui dini bagi ibu bersalin yang negatif CoViD-19. Penelitian yang dilakukan oleh Nurhidayat Triananinsi (2021) bahwa pentingnya pijat oksitosin untuk memperlancar ASI bagi ibu bersalin, sehingga untuk mengajarkan atau membimbing ibu bersalin dalam mengetahui titik oksitosin dan pemijatan dibutuhakn kontak langsung antara tenaga kesehatan dan ibu bersalin (Triananinsi, 2021).

Output penelitian berdasarkan pengetahuan dan sikap ibu bersalin terhadap upaya tenaga kesehatan dalam pelayanan persalinan selama masa pandemi CoViD-19. Jika dilihat dari pengetahuan ibu hamil sebagian besar (55\%) berpengetahuan cukup, 40\% yang mempunyai pengetahuan baik, walau sisanya (5\%) berpengetahuan kurang. Output berdasarkan pengetahuan dapat dilihat pada gambar 2 .

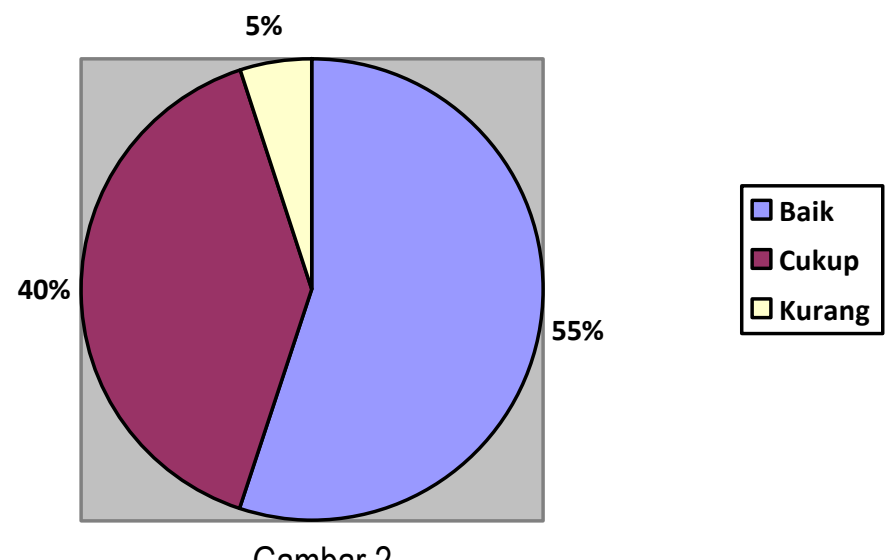

Gambar 2.

Pengetahuan Ibu bersalin terhadap pelayanan persalinan selama masa CoViD-19

Sedangkan output sikap ibu bersalin dalam menanggapi pelayanan persalinan yang diberikan selama masa pandemi CoViD-19 menunjukkan sikap mendukung secara totalitas (100\%). Terdapat beberapa sikap ibu bersalin yang perlu menjadi perhatian dan masukan bagi pelayanan persalinan 


\section{Mudyawati Kamaruddin, Andi Reski Sulpianti, Haerani, Erniawati, Jusni, Artita, Asviratul Annatasia, Nurhidayat Triananinsi}

di masa depan saat pandemi berikutnya muncul adalah sebagaimana yang diperlihatkan grafik pada
Gambar 3 di bawah ini:

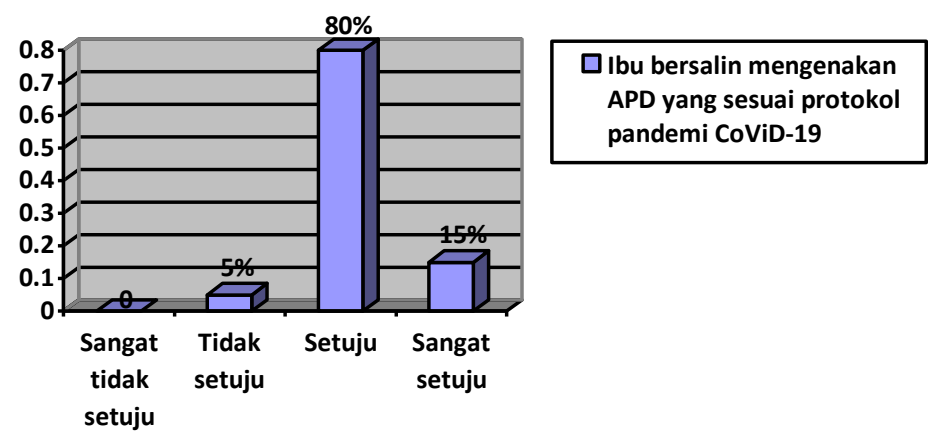

Gambar 3.

Sikap Ibu hamil terhadap penggunaan APD

Gambar 3 terlihat bahwa sikap ibu menunjukkan sikap positif mengenai penggunaan alat pelindung diri selama proses persalinan, kunjungan petugas dan keluarga, hal ini sesuai dengan anjuran dan mengikuti pedoman terkait pandemi CoViD-19, walaupun ada beberapa ibu bersalin tidak setuju, kemungkinan karena faktor tidak biasa dengan APD sehingga menimbulkan kegerahan.

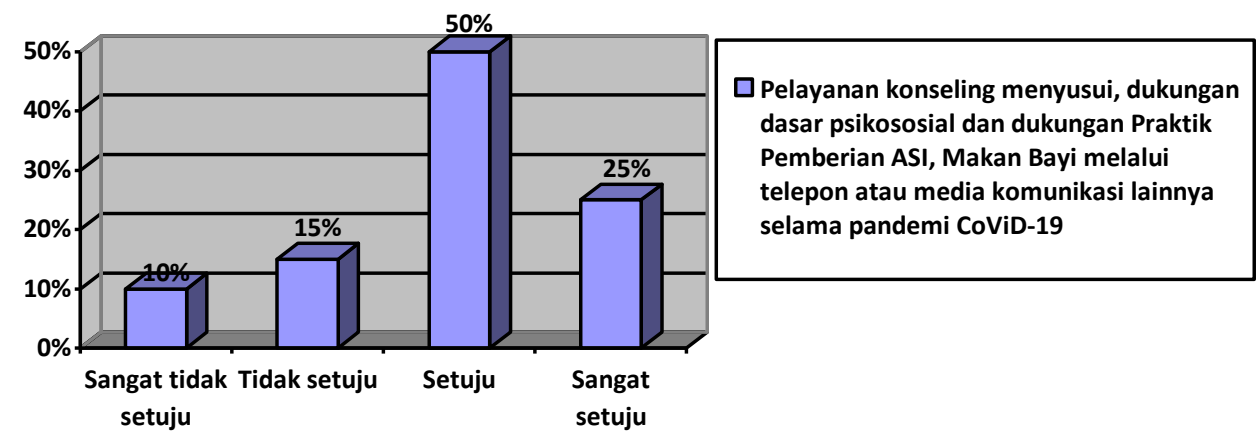

Gambar 4.

Sikap Ibu hamil terhadap penggunaan Pelayanan konseling selama masa pandemi CoViD-19 melalui media komunikasi ke tenaga kesehatan

Pada Gambar 4 di atas sikap ibu bersalin dapat dilihat pada grafik bahwa $50 \%$ ibu bersalin setuju dengan pemberian konseling melalui online, baik melalui telefon maupun media komunikasi lainnya. Menurut Pedoman Pelayanan persalinan di Era Adaptasi Kebiasaan Baru bahwa pelaksanaan konseling menyusui, dukungan dasar psikososial dan dukungan praktik pemberian ASI, makan bayi selama masa pandemi CoViD-19 dilakukan secara online atau melalui media sosial. Walaupun tidak sedikit pula yang tidak setuju. Pada pertanyaan mengenai pelayanan konseling seperti yang diperlihatkan pada Gambar 4, menunjukkan bahwa masyarakat sudah paham atas situasi pandemi CoViD-19, paham akan akibat dan efek yang ditimbulkan jika tidak menaati regulasi terkait pandemi.

\section{PEMBAHASAN \\ Karakterik Responden}

Berdasarkan hasil penelitian jika ditinjau dari karateristik responden sebagian besar responden masuk dalam kategori usia reproduksi sehat, sebagain besar responden berada pada pendidikan tinggi. Tingkat pendidikan seseorang juga mempengaruhi dalam pemanfaatan pelayanan kesehatan sebagaimana hasil penelitian dari Mudyawati Kamaruddin $(2019,2021)$, Siti Usmia (2020) dan Jusni (2020) bahwa tingkat pendidikan responden yang tinggi sejalan dengan tingkat pengetahuan yang mumpuni dan akan memberikan lebih banyak kemanfaatan dalam bersikap yang lebih positif (Kamaruddin, 2021; Kamaruddin, 2019; Usmia, 2020; Jusni,. 2020). Pada penelitian ini, 


\section{JKM (Jurnal Kebidanan Malahayati),Vol 7,No.4.Oktober 2021, ISSN (Print) 2476-8944 ISSN (Online) 2579-762X, Hal 626-633}

responden ibu bersalin sebagian besar responden tidak bekerja atau menjadi ibu rumah tangga.

Selain itu, paritas responden menunjukkan tidak ada yang tergolong ke dalam faktor risiko ibu hamil karena tidak ada responden yang mempunyai anak (Nullipara) atau pernah melahirkan lebih dari empat kali.

\section{Pelaksanaan Pelayanan Persalinan}

Pelayanan kesehatan khususnya pelayanan persalinan, yaitu bidan melaksanakan kegiatan berdasarkan pedoman yang sudah ditetapkan oleh pemerintah dan mematuhi protokol kesehatan baik keseharian maupun dalam ruangan persalinan di Rumah Sakit. Kondisi pandemi CoViD-19 saat ini menyebabkan berubahnya beberapa hal dalam pelayanan, petugas kesehatan harus mengubah metode pelayanan. Demikian juga pelayanan persalinan yang dilakukan oleh bidan dengan konseling melalui media komunikasi seperti telfon maupun media sosial. Materi yang diberikan berupa konseling dan bimbingan menyusui, dukungan dasar psikososial dan dukungan praktik pemberian ASI, dan makanan bayi.

Pengetahuan ibu bersalin juga ikut mendukung kelancaran pelaksanaan pelayanan persalinan oleh tenaga bidan, hal ini dimungkinkan karena arahan-arahan yang terkait dengan pencegahan penyakit yang disebabkan oleh virus CoViD-19 dapat dipahami dan dilaksanakan sesuai prosedur. Seperti hasil penelitian yang dilakukan oleh Damopolii (2015) bahwa pengetahuan atau kognitif merupakan domain yang sangat penting untuk terbentuknya tindakan seseorang (Damopolii, 2015).

Pelaksanaan pelayanan persalinan selama masa pandemi CoViD-19 petugas kesehatan melakukan pelayanan berdasarkan pedoman yang ditetapkan pemerintah. Kementerian Kesehatan telah mengeluarkan Pedoman Pelayanan Bagi Ibu Hamil, Bersalin. Nifas dan Bayi Baru Lahir baik saat era pandemi CoViD-19 maupun era adaptasi kebiasaan baru. Pedoman yanmg dikeluarkan oleh Kementerian Kesehatan itu disosialisasikan oleh dinas kesehatan kepada kepala puskesmas untuk diterapkan dalam pemberian pelayanan kesehatan kepada masyarakat (Mugiati dan El Rahmayati, 2021). Petugas kesehatan khususnya bidan dalam memberikan pelayanan persalinan berdasarkan pedoman tersebut (era pandemi CoViD-19) antara lain: Ibu tetap bersalin di fasilitas pelayanan kesehatan. Segera ke fasilitas kesehatan jika sudah ada tanda-tanda persalinan; Rujukan terencana untuk ibu hamil berisiko; tempat pertolongan persalinan ditentukan berdasarkan: a) kondisi ibu sesuai dengan level frasyankes penyelenggara pertolongan persalinan, dan b) status ibu orang dalam pengawasan (ODP), PDP, terkonfirmasi CoViD-19 atau bukan ODP/PDP/CoViD-19; lbu dengan status ODP, PDP atau terkonfirmasi CoViD19 bersalin di rumah sakit rujukan CoViD-19; Ibu dengan status BUKAN ODP, PDP atau terkonfirmasi CoViD-19 bersalin di fasyankes sesuai kondisi kebidanan (bisa di FKTP atau FKTRL); Saat merujuk pasien ODP, PDP atau terkonfirmasi CoViD-19 sesuai dengan prosedur pencegahan CoViD-19; dan pelayanan KB pasca persalinan tetap dilakukan sesuai prosedur, dan diutamakan menggunakan MKJP (Kemenkes, 2020):

Pelayanan persalinan berdasarkan pedoman era pandemi CoViD-19 antara lain: Pemilihan metode persalinan juga harus mempertimbangkan ketersediaan sumber daya, fasilitas di rumah sakit, tata ruang perawatan rumah sakit, ketersediaan APD, kemampuan laksana, sumber daya manusia, dan risiko paparan terhadap tenaga medis dan pasien lain; Indikasi induksi persalinan atau SC sesuai indikasi obstetrik, indikasi medis, atau indikasi kondisi ibu atau janin; Ibu dengan CoViD-19 yang dirawat di ruang isolasi di ruang bersalin, dilakukan penanganan tim multidisiplin yang terkait meliputi dokter paru/penyakit dalam, dokter kebidanan dan kandungan, anestesi, bidan, dokter spesialis anak dan perawat perinatologi; Upaya harus dilakukan untuk meminimalkan jumlah anggota staf yang memasuki ruangan dan unit, harus ada kebijakan lokal yang menetapkan personil yang ikut dalam perawatan. Hanya satu orang (pasangan/ anggota keluarga) yang dapat menemani pasien. Orang yang menemani harus diinformasikan mengenai risiko penularan dan mereka harus memakai APD yang sesuai saat menemani pasien; Pengamatan dan penilaian ibu harus dilanjutkan sesuai praktik standar, dengan penambahan pemeriksaan saturasi oksigen yang bertujuan untuk menjaga saturasi oksigen $>94 \%$, titrasi terapi oksigen sesuai kondisi; Menimbang kejadian penurunan kondisi janin pada beberapa laporan kasus di Cina, apabila sarana memungkinkan dilakukan pemantauan janin secara kontinyu selama persalinan; Bila ada indikasi operasi terencana pada ibu hamil dengan suspek atau terkonfirmasi COVID-19, dilakukan evaluasi urgency-nya, dan apabila memungkinkan ditunda untuk mengurangi risiko penularan sampai infeksi terkonfirmasi atau keadaan akut sudah teratasi. Apabila operasi tidak dapat ditunda maka operasi dilakukan sesuai prosedur standar dengan pencegahan infeksi sesuai standar APD; Persiapan operasi terencana dilakukan sesuai standar; Seksio 


\section{Mudyawati Kamaruddin, Andi Reski Sulpianti, Haerani, Erniawati, Jusni, Artita, Asviratul Annatasia, Nurhidayat Triananinsi}

sesarea dapat dilaksanakan di dalam ruangan bertekanan negatif atau dapat melakukan modifikasi kamar bedah menjadi bertekanan negatif (seperti mematikan AC atau modifikasi lainnya yang memungkinkan); Apabila ibu dalam persalinan terjadi perburukan gejala, dipertimbangkan keadaan secara individual untuk melanjutkan observasi persalinan atau dilakukan seksio sesaria darurat jika hal ini akan memperbaiki usaha resusitasi ibu; Ruang operasi kebidanani meliput : Operasi elektif pada pasien COVID-19 harus dijadwalkan terakhir; pasca operasi, ruang operasi harus dilakukan pembersihan penuh sesuai standar; Jumlah petugas di kamar operasi seminimal mungkin dan menggunakan APD sesuai standar; Antibiotik intrapartum harus diberikan sesuai protokol; Plasenta harus ditangani sesuai praktik normal. Jika diperlukan histologi, jaringan harus diserahkan ke laboratorium, dan laboratorium harus diberitahu bahwa sampel berasal dari pasien suspek atau terkonfirmasi CoViD-19; Berikan anestesi epidural atau spinal sesuai indikasi dan menghindari anestesi umum kecuali benar-benar diperlukan; Dokter spesialis anak dan tim harus diinformasikan terlebih dahulu tentang rencana pertolongan persalinan ibu dengan COVID-19, agar dapat melakukan persiapan protokol penanganan bayi baru lahir dari ibu tersebut (Kemenkes, 2020):

\section{Luaran dalam Pelaksanaan Pelayanan Persalinan}

Output penelitian berdasarkan pengetahuan dan sikap ibu bersalin terhadap upaya tenaga kesehatan dalam pelayanan persalinan selama masa pandemi CoViD-19. Pengetahuan adalah kemampuan seseorang tentang sesuatu. Kemampuan yang paling rendah tetapi paling dasar dalam kawasan kognitif. Kemampuan untuk mengetahui adalah kemampuan untuk mengenal atau meningkatkan kembali suatu objek, ide, prosedur, prinsip, atau teori yang pernah ditemukan dengan pengalaman tanpa memanipulasinya. Pengetahuan atau kognitif merupakan domain yang sangat penting dalam bentuk tindakan seseorang. Dari pengalaman dan penelitian terbukti bahwa perilaku yang didasari oleh pengetahuan akan lebih langgeng dari pada perilaku yang tidak didasari oleh pengetahuan (Soekanto, 2015). Sedangkan penelitian yang telah dilakukan dengan teori yang ada, peneliti menyimpulkan bahwa pengetahuan sangat berperan dalam sikap seseorang, dimana semakin baik pengetahuan seseorang maka semakin besar pula kapasitas dalam bersikap baik terhadap sesuatu.
Jika dilihat dari pengetahuan ibu hamil sebagian besar (55\%) berpengetahuan cukup, 40\% yang mempunyai pengetahuan baik, walau sisanya $(5 \%)$ berpengetahuan kurang (Gambar 2). Pada hasil penelitian ini menjelaskan dari 20 responden, ibu bersalin yang berpengetahuan baik yaitu 8 responden $(40 \%)$, yang berpengetahuan kurang 1 responden $(5 \%)$, hampir semua berpengetahuan cukup yaitu 11 responden (55\%). Hal ini kemungkinan disebabkan oleh pengetahuan yang diperoleh dari pengalaman dan wawasan tersendiri dari ibu bersalin, dan dalam penelitian ini responden dengan jumlah 20 orang ibu bersalin terdapat perbedaan presepsi bahkan salah sehingga mendapatkan hasil yang dominan cukup, selain itu pengumpulan data melalui lembar kuesoner secara langsung yang diberikan melaui telfon WhatsApp oeh responden sehingga kualitas data yang dikumpulkan dam peneitian sangat tergantung dari kemampuan dan kejujuran responden dalam menjawab setiap pernyataan atau pertanyaan.

Sedangkan output sikap ibu bersalin dalam menanggapi pelayanan persalinan yang diberikan selama masa pandemi CoViD-19 menunjukkan sikap mendukung secara totalitas (100\%). Terdapat beberapa sikap ibu bersalin yang perlu menjadi perhatian dan masukan bagi pelayanan persalinan di masa depan saat pandemi berikutnya muncul adalah sebagaimana yang diperlihatkan grafik pengetahuan seseorang terhadap sesuatu hal, sikap juga dilandasi oleh pengetahuan seseorang (Notoatmodjo, 2014). Sebagaimana hasil penelitian Khusna (2016) yang mendapatkan hasil bahwa sikap juga berhubungan dengan pemanfaatan sarana pelayanan kesehatan dimana pemanfaatan pelayanan antenatal di Puskesmas Pegandan (Khusna, 2016).

Kondisi pandemi CoViD-19 secara khusus membatasi penelitian ini untuk mendapatkan data yang lebih detail, lengkap dan cukup banyak sampel, hal ini dikarenakan komunikasi yang terbatas hanya lewat media social (WhatsApp) dimana signal juga tidak mendukung bagi lbu bersalin yang berada di tepi kota Bantaeng.

\section{SIMPULAN}

Pengetahuan ibu bersalin terhadap pelaksanaan pelayanan persalinan selama masa pandemi Covid-19 di RSUD Prof. Dr. H. M. Anwar Makkatutu Bantaeng, Sulawesi Selatan sesuai dengan pelayanan dan pengaplikasian protokol kesehatan selama panemi CoViD-19 oleh tenaga kesehatan di RSUD. Pengetahuan yang baik didukung dengan sikap yang positif terhadap perubahan-perubahan pelayanan ditunjukan oleh 


\section{JKM (Jurnal Kebidanan Malahayati),Vol 7,No.4.Oktober 2021, \\ ISSN (Print) 2476-8944 ISSN (Online) 2579-762X, Hal 626-633}

ibu bersalin, dan bahwa masyarakat sudah paham atas situasi pandemi CoViD-19, paham akan akibat dan efek yang ditimbulkan jika tidak menaati regulasi terkait pandemic CoViD-19.

\section{SARAN}

Diharapkan penelitian selanjutnya dapat berupa penindaklanjutan analisis pelayanan kesehatan di Rumah Sakit baik di kota maupun di tingkat daerah yang beracuan pada protokol kesehatan pada masa setelah pandemi CoViD-19.

\section{DAFTAR PUSTAKA}

Damopolii, T. A. J., Kundre, R., \& Bataha, Y. (2015). Hubungan Standar Pelayanan Antenatal Care Dan Kebijakan Program Pelayanan Antenatal Care Dengan Pengetahuan Antenatal Care Terintegrasi Di Wilayah Kerja Puskesmas Gogagoman Kota Kotamobagu. Jurnal Keperawatan, 3(2).

Erniawati, \& Kamaruddin, M. (2020). Asuhan Kebidanan Pasca Salin (1st ed.). Manggu Makmur Tanjung Lestari.

Jusni, Mariana, R., Misriyani, Erniawati, Handayani, I., Nurhayani, Triananinsi, N. Kamaruddin, M. (2020). Deskripsi Pengetahuan dan Sikap Mahasiswi terhadap HIV dan AIDS di Akademi Kebidanan Tahirah Al Baeti Bulukumba. Medika Alkhairaat: Jurnal Penelitian Kedokteran dan Kesehatan, 3(2), 86-89. DOI: 10.31970/ma.v2i1.47

Kamaruddin, M., Hasrawati, Usmia, S., Jusni, Misnawaty, \& Handayani, I. (2019). Korelasi antara Status Gizi dan Kadar Hemoglobin pada Kejadian Anemia Ibu Hamil Trimester III. Medika Alkhairaat: Jurnal Penelitian Kedokteran dan Kesehatan, 1(2), 77-82.

Kamaruddin, M., Purnamasari, D., Fitriani. (2021). Pengetahuan dan Sikap Siswi Menengah Pertama tentang Dismenore di Bulukumba. Medika Alkhairaat: Jurnal Penelitian Kedokteran dan Kesehatan, 3(2), 86-89. DOI: 10.31970/ma.v3i2.79
Kamaruddin, M., Usmia, S. (2019). Deskripsi Pengetahuan dan Sikap Ibu Hamil Trimester III tentang Senam Hamil. Medika Alkhairaat: Jurnal Penelitian Kedokteran dan Kesehatan, 1(2), 45-49

Khusna, Riyadhotul. (2016). Analisis Faktor-Faktor Yang Mempengaruhi Pemanfaatan Pelayanan Antenatal Di Puskesmas Pegandan Kota Semarang. [Skripsi]. Semarang: Fakultas IImu Keolahragaan, Universitas Negeri Semarang.

Kusmiwiyati, A., \& Triningsih, R. W. (2018). Hubungan Pijat Oksitosin Dengan Penurunan TFU dan Pengeluaran Lochea pada Ibu Postpartum Normal. Jurnal Kebidanan, X(2), 60-69.

Lothian, J. A. (2019). Healthy Birth Practice \#4: Avoid Interventions Unless They Are Medically Necessary. The Journal of Perinatal Education, 28(2), 94-103. http://dx.doi.org/10.1891/1058-1243.28.2.94

Mugiati dan El Rahmayati (2020). Analisis Pelaksanaan Pelayanan Antenatal pada Masa Pandemi CoViD-19. Jurnal Kesehatan, 2(1), 147-155

Notoadmodjo, S. (2012). Metodelogi Penelitian Kesehatan, Jakarta: PT .Rineka Cipta.

Triananinsi, N., Syarif, S., \& Kamaruddin, M. (2021). Pijat Oksitosin Mempengaruhi Kelancaran ASI. Jurnal Antar Pengabmas. 4(2), 5.

Usmia, S., Haerani, Wahyuni, S., Misriyani, Kamaruddin, M. (2020). Deskripsi Pengetahuan lbu tentang KB Suntk 3 Bulan (Depo Progestin) di Puskesmas Bontobahari, Bulukumba. Medika Alkhairaat: Jurnal Penelitian Kedokteran dan Kesehatan, 2(2), 179-186. DOI: 10.31970/ma.v2i2.53

Zhu H, Wang L, Fang C, Peng S, Zhang L, Chang $\mathrm{G}$, et al. Clinical analysis of 10 neonates born to mothers with 2019- nCoV pneumonia. Transl Pediatr 2020;9:51-60. Available at: http://tp.amegroups.com/article/view/35919/2 8274. Retrieved February 21, 2020. 